\title{
Utilizing Sewage Wastewater Heat in District Heating Systems in Serbia - Effects on Sustainability
}

\section{Marija Živković}

University of Belgrade, Faculty of Mining and Geology

Dejan Ivezic ( $\sim$ dejan.ivezic@rgf.bg.ac.rs )

University of Belgrade - Faculty of Mining and Geology https://orcid.org/0000-0003-2659-0662

\section{S.I. : SDEWES_2020}

Keywords: Sewage Wastewater Heat Recovery, District Heating Systems, Heat Pumps, Energy Savings, Carbon Dioxide Emission, Energy Security, Serbia

Posted Date: February 4th, 2021

DOI: https://doi.org/10.21203/rs.3.rs-157558/v1

License: (c) (i) This work is licensed under a Creative Commons Attribution 4.0 International License.

Read Full License

Version of Record: A version of this preprint was published at Clean Technologies and Environmental Policy on March 14th, 2021. See the published version at https://doi.org/10.1007/s10098-021-02063-6. 


\title{
Utilizing Sewage Wastewater Heat in District Heating Systems in Serbia - Effects on Sustainability
}

\author{
MarijaŽivković \\ University of Belgrade - Faculty of Mining and Geology, Belgrade, Serbia \\ e-mail: marija.živković@rgf.bg.ac.rs \\ DejanIvezić \\ University of Belgrade - Faculty of Mining and Geology, Belgrade, Serbia \\ e-mail: dejan.ivezić@rgf.bg.ac.rs
}

\begin{abstract}
Transformation of the heating sector is recognized as being essential for ensuring reliable and affordable energy services provided with reduced consumption of energy sources, diminished impact on the environment and less import dependency. The possibility of utilizing energy sources that otherwise would be wasted needs to be considered and treated as a big advantage of district heating systems. Despite many advantages, sewage wastewater heat is still a mostly unused resource at the global level and a totally unused energy source in Serbia, while data about the potential of this energy source are lacking. This research proposes a methodology for the determination of the technical potential of waste heat from wastewater treatment facilities for use in district heating systems by heat pump application. Data from existing wastewater treatment facilities are used for providing data for replication in cities without wastewater treatment plants but with district heating systems. An estimation of the recoverable heat energy potential of wastewater is used for evaluation of some effects that could be obtained through its full utilization for heat production in the existing district heating systems. Three groups of indicators are selected for analysis focusing on district heating systems' energy performance (primary energy factor, specific heat consumption per degree day and heating area), the security of energy supply (import dependency, Shannon Wiener diversification index, the share of renewables) and environmental impact (carbon dioxide emission coefficient). Values of the selected indicators are determined for the current state of district heating systems and for the possible future state that could be achieved after full utilization of sewage wastewater potential. The proposed methodology is applied to Serbia, as a case study. It has been shown that all analyzed indicators for the projected future would have more preferable values compared to the values that correspond to the current state of the district heating systems. The use of this renewable energy source should provide primary energy savings of $5 \%$ per year, reduction of carbon dioxide emission of $6.5 \%$ per year, reduction of import dependency of DH systems of $9.8 \%$ and improved diversification of energy sources of $21 \%$.
\end{abstract}

\section{KEYWORDS}

Sewage Wastewater Heat Recovery; District Heating Systems; Heat Pumps; Energy Savings; Carbon Dioxide Emission; Energy Security; Serbia

NOMENCLATURE

\begin{tabular}{|c|l|}
\hline DH & district heating \\
\hline GHG & Green House Gases \\
\hline HP & heat pump \\
\hline$f_{p}$ & primary energy factor \\
\hline$E_{i}$ & energy content of input to the system of the $\mathrm{i}^{\text {th }}$ energy carrier \\
\hline $\mathrm{f}_{\mathrm{p}, \mathrm{i}}$ & primary energy factor of the $\mathrm{i}^{\text {th }}$ energy carrier \\
\hline $\mathrm{Q}_{\mathrm{ext}}$ & externally supplied heat \\
\hline $\mathrm{f}_{\mathrm{p}, \mathrm{ext}}$ & primary energy factor of the external heat supply \\
\hline $\mathrm{E}_{\mathrm{el}, \mathrm{aux}}$ & auxiliary electricity \\
\hline $\mathrm{f}_{\mathrm{p}, \mathrm{el}}$ & primary energy factor for electricity production \\
\hline $\mathrm{Q}_{\mathrm{del}, \mathrm{j}}$ & delivered heat to the $\mathrm{j}^{\text {th }}$ consumer \\
\hline $\mathrm{q}_{\mathrm{DD}}$ & useful annual heat supplied per Degree Day and heating area \\
\hline
\end{tabular}




\begin{tabular}{|c|l|}
\hline $\mathrm{DD}$ & number of degree days \\
\hline $\mathrm{Ai}$ & heating area of the $\mathrm{i}^{\text {th }}$ consumer \\
\hline $\mathrm{I}_{\mathrm{d}}$ & import dependency \\
\hline $\mathrm{p}_{\mathrm{i}}$ & fraction of the $\mathrm{i}^{\text {th }}$ input energy carrier/fuel in the fuel mix $\left(\sum \mathrm{p}_{\mathrm{i}}=1\right)$ \\
\hline $\mathrm{I}_{\mathrm{d}, \mathrm{i}}$ & import dependency of the $\mathrm{i}^{\text {th }}$ energy carrier/fuel \\
\hline $\mathrm{H}$ & Shannon Wiener index \\
\hline $\mathrm{F}_{\mathrm{RES}}$ & share of renewable energy sources \\
\hline $\mathrm{E}_{\mathrm{i}, \mathrm{RES}}$ & energy content of input to the system of the $\mathrm{i}^{\text {th }}$ renewable energy carrier \\
\hline $\mathrm{Q}_{\text {ext,RES }}$ & externally supplied heat produced from renewables \\
\hline $\mathrm{K}_{\mathrm{p}, \mathrm{dh}}$ & carbon dioxide emission coefficient \\
\hline $\mathrm{E}_{\mathrm{i}}$ & energy content of input to the system of the $\mathrm{i}^{\text {th }}$ energy carrier \\
\hline $\mathrm{K}_{\mathrm{pi}}$ & primary CO ${ }_{2}$-emission coefficient of the $\mathrm{i}^{\text {th }}$ energy carrier \\
\hline $\mathrm{K}_{\mathrm{ext}}$ & primary CO ${ }_{2}$ emission coefficient of externally supplied heat \\
\hline $\mathrm{K}_{\mathrm{el}}$ & carbon dioxide emission coefficient of electricity \\
\hline$\dot{\mathrm{Q}}_{\mathrm{W}}$ & recoverable heat power treated sewage wastewater \\
\hline$\dot{\mathrm{m}}$ & mass flow of treated wastewater \\
\hline$\Delta \mathrm{t}$ & temperature difference of treated wastewater at entrance and exit of heat exchanger- \\
\hline$\dot{\mathrm{Q}}_{\mathrm{h}}$ & evaporator \\
\hline $\mathrm{COP}$ & thermal power of heat pumps \\
\hline$\Delta \mathrm{t}_{\text {lift }}$ & teefficient of performance \\
\hline $\mathrm{Q}_{\mathrm{HP}}$ & heat energy produced by heat pumps \\
\hline $\mathrm{q}_{\mathrm{HP}}$ & availability of heat energy \\
\hline $\mathrm{n}$ & number of inhabitants \\
\hline $\mathrm{q}_{\mathrm{PE}}$ & primary energy savings in $\mathrm{i}^{\text {th }}$ DH system \\
\hline $\mathrm{PE}$ & population equivalent \\
\hline$\eta$ & represents the efficiency of heat production in the existing DH system \\
\hline & \\
\hline
\end{tabular}

\section{INTRODUCTION}

Cities are responsible for more than two thirds of the world's energy consumption (International Energy Agency, 2016). Being heavily dependent on fossil fuels, energy use in urban areas currently generates more than $70 \%$ of global greenhouse gas (GHG) emissions. The major share of energy consumed in urban areas is related to heating needs, while fossil fuels make approximately 75\% of consumption in this sector (International Energy Agency, 2014). Thus, the heating sector has a decisive role in the energy transition to more sustainable energy systems. Transformation of the heating sector could substantially contribute to reaching goals of sustainable development.

Transformation of energy systems should be directed towards ensuring reliable and affordable energy services, provided with reduced consumption of energy sources, impact on the environment and import dependency (United Nations, Sustainable Development Goals). Transition to more sustainable systems can be achieved by acting on the demand and supply side. In the previous period, much attention was paid to the demand side, by retrofitting the building stock, but lately, the supply side has received more attention in the EU (European Commission, 2016). Actions on the supply side should be directed to the decarbonization of the heating sector by using renewable energy sources or introducing more efficient energy utilization methods.

Wastewater heat can be considered as an alternative, renewable, and locally available energy source. In the cities, almost $40 \%$ of produced heat is delivered to the sewage system as waste heat (Hepbasli et al., 2014). It has been estimated that the daily amount of wastewater delivered to sewage system per person comprises $85 \%$ of the total amount of persons daily water demand (Hepbasli et al., 2014). Sewage wastewater is characterized by a small variation of flow rate and temperature over the year (Meggers and Leibundgut, 2011). Due to the high heat capacity and density, wastewater is considered as a suitable heat source for implementation in heat pumps (HP) systems, whose operation is based on simple and proven technology (Hepbasli et al., 2014). Sewage waste heat is more long-term resilient comparing to industrial or excess heat (Averfalk et al., 2017). Despite all quoted advantages, wastewater heat is still a mostly unused resource at the global level (Intelligent energy Europe, 2017).

More intensive utilization of sewage wastewater heat could be achieved by the integration of heat pumps in district heating (DH) systems (Averfalk et al., 2017). In (Sayegh et al., 2018), four scenarios of possible integration of heat pumps in district heating systems were identified: a) Heat pump placement into the existing network without 
major changes, (b) Heat pump placement in an expanded network, (c) Deep refurbishment of the existing district heating system, and d) The design of a new district heating system supplied by a heat pump. By implementing one of the options, heat demands of customers in urban areas can be served by exploiting surplus heat that would have otherwise been dissipated. This will result in energy savings, increase of renewable share in the energy mix, decrease of greenhouse gases emissions and air pollution in the cities, which is a promising solution for shifting towards environmentally acceptable, resource-independent cities (Lu et al., 2020).

Selection of an appropriate heat pump is strongly driven by characteristics of available heat source. Besides selection of the appropriate heat pump technology, the heat source has influence on the placement of the heat pump unit, connection and operational modes, appropriate thermal capacity and range of operational temperatures for the system (Sayegh et al., 2018). These issues were analyzed for the cases where heat pumps were successfully implemented and integrated in district heating systems. Some operational aspects of large heat pumps in the Swedish district heating system (capacity utilization, competitiveness, refrigerant management, and refrigerant leakage) are presented in (Averfalk et al., 2017). (Kontu, et al., 2019), assessed the feasibility of introducing heat pumps to existing DH systems without jeopardizing the profitability of current production plants. Different sized DH systems have been simulated to explore how increasing the share of heat pump production influences DH systems. Data on heat pump performance in an Olympic village in Vancouver are given in (Fiore and Genon, 2014). Technical data and analyses of effectiveness of a heat pump installation in Vladivostok are discussed in (Leonid et al., 2014). Spatial and temporal considerations of the performance of wastewater heat recovery systems are discussed in (Spriet et al., 2020).

In the previous period, besides analyses of technical and operational aspects, a number of studies have been conducted to evaluate environmental impacts of wastewater heat utilization. (Meunier, 2004) analyzed effects on carbon dioxide emission reduction of absorption waste heat pumps application for space heating. (Mateu-Royo et al., 2020) presented the thermo-economic optimization, focusing on performance of the system and environmental analysis. (Kollmann et al., 2016) proposed a novel method to assess the integration of wastewater treatment plants (WWTPs) into local energy supply concepts. The method addresses spatial, economic and environmental perspectives.

Different approaches for evaluation of wastewater heat potential, either on state or city level, were presented in several studies. (Neugebauer et al., 2015) calculated the heat energy potential of Austrian wastewater treatment plants (larger than 2000 population equivalents). (Sarpong et al., 2020) evaluated energy recovery potential in wastewater treatment facilities. including codigesting of sewage sludge. (Maddah et al., 2020) presented a thermoeconomic-environmental analysis of heat recovery potential from the Iranian industry sector and calculated natural gas savings and carbondioxide reduction. (Somogyi et al., 2018) determined the potential of wastewater excess heat that could be used in district heating systems in Hungary. GIS tools were used for identification of areas where the excess heat could be used, taking into consideration the distance between heat sources and areas with DH. Analysis of economic feasibility of wastewater heat utilization showed the strong influence of the distance between WWTP and DH systems (Santin et al., 2020). (Đurdević et al, 2019) analyzed and determined the potential for utilizing wastewater heat for heating the city of Rijeka. They evaluated heat production with different values of COP, depending on the temperature of the supply water in the district heating system and calculated related reduction of carbondioxide emission. In all this research, the potential of waste heat was evaluated based on operational data of existing facilities. However, in most of developing countries (such as Serbia) wastewater treatment plants are rare, or in the preparation phase, so presented methodologies cannot be applied.

Although it is evident that utilization of renewable energy sources has a positive effect in mitigating climate change, it is still not a strong enough driver for wider implementation of renewable energy sources (Duić, 2015). Some other effects, such as security of supply, might be stronger incentive for investing in alternative energy sources.

Quantification of the effects of wastewater heat utilization on security of supply, has not been analyzed in the literature so far. Thus, this paper presents a methodology that aims to quantify and determine a range of positive effects that can be achieved with the introduction of electrically driven heat pumps. These effects are in relation with the goals of sustainable development and include energy security, reduction of fossil fuel consumption, and climate change mitigation. The proposed approach includes determination of technical potential of waste heat based on data from existing wastewater treatment facilities and a simulation of heat energy production by heat pumps. The effects on sustainability are assessed through analysis of key performance indicators to provide deeper insight in energy efficiency, energy security, and carbon dioxide emission of district heating systems (primary energy factor, import dependency index, fuel mix diversification, and carbon dioxide emission). Selected indicators are calculated for the current state and for a possible future state of district heating systems which would 
utilize the previously determined full technical potential of wastewater heat. The proposed methodology can be applied on the levels of city, region, or a state, taking into account specifics of heat and electricity generation and the structure of primary energy supply. In addition, the methodology provides a possibility for estimation of the technical potential of wastewater heat for cities without WWTP. This information can be valuable in the preparation phase and WWTP location selection.

In this paper, the proposed methodology was applied for Serbia as a case study, assuming a scenario of integration of heat pumps in the existing district heating systems without major changes. Currently in Serbia. sewage waste heat is not utilized at all. Moreover, there are no available data about sewage waste heat potential at the level of the state, regions, or cities (Ministry of Mining and Energy, 2015). The technical potential of sewage wastewater heat is estimated and some of the effects that could be obtained through its utilization for heat production in the existing district heating systems (assuming a scenario of integration of heat pumps in the existing district heating systems without major changes) are evaluated. It has been shown that all proposed indicators for the projected future would have more desirable values compared to the values that correspond to the current state of district heating systems.

\section{METHODOLOGY}

The methodology for determination of technical potential of sewage wastewater heat, availability of heat energy and evaluation of the effects of its utilization on sustainable development goals contains three parts (Figure 1).

The first part aims to provide a current state overview of existing district heating systems, supported with values of selected key performance indicators for the reference year, which will serve as reference values to be compared with.

The second part is related to determination of the recoverable heat energy potential of treated sewage wastewater. As the aim of this research is to estimate the potential of this energy source in the cities without WWTP (but with plans for WWTP construction in the future), the heat energy that could be produced from the WWTP and related primary energy savings are calculated for the selected city with WWTP in operation. The obtained energy amounts are set in relation to the number of inhabitants of the selected city. In that way, the indicator of energy availability (which provides information about heat energy produced utilizing waste heat per capita) is obtained, as well as an indicator of primary energy savings per capita. These indicators provide the basis for the estimation of recoverable heat energy potential for other cities, with district heating systems and plans for WWTP construction, as well as for the evaluation of effects of utilization of full potential.

Based on the outcomes from the first and second parts, the projection of the future state of district heating systems is conducted, making preconditions for determination of the key performance indicators of such systems. For projection of the future energy mix, it is assumed that heat delivered by heat pumps will firstly substitute coal, then heavy oil and at the end natural gas. Such an approach and order of substitution is governed by the need for maximizing the reduction of GHG emission and air pollution in the cities. For the projection of the future state of district heating systems, the heating area and efficiency of the buildings, district heating plants and networks are assumed to be the same as in the reference year. Thus, load curves of DH systems would have unchanged shapes, while values of indicators in the base year (current state) and values for the projection would be comparable, and the effects of utilizing wastewater heat can be evaluated. 


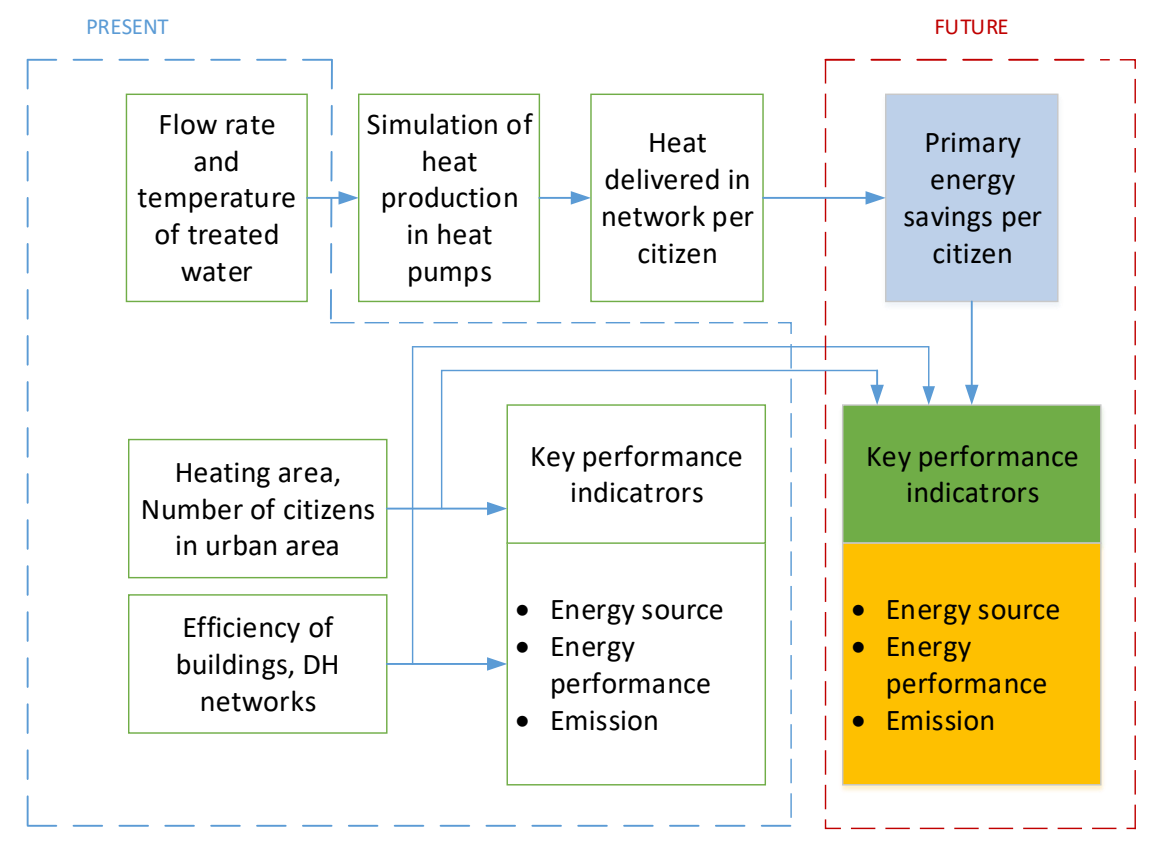

Figure 1. Methodology for evaluation of effects of full recoverable wastewater heat energy potential utilization in district heating systems with heat pumps

\subsection{Key performance indicators}

For the evaluation, comparison and analysis of the current and possible state of district heating systems three groups of indicators are selected focusing on energy performance, energy supply, and environmental impact.

\section{Energy performance.}

The Primary Energy Factor $\left(\mathbf{f}_{\mathbf{p}}\right)$ determines the primary energy required to supply one unit of useful energy to the consumer. The Primary Energy Factor is calculated by using the methodology given in the European Standard EN 15316-4-5 (Standard EN 15316-4-5, 2017). System boundaries for determining the Primary Energy Factor are presented in Figure 2.

Evaluation of the primary energy includes the complete supply chain of the fuel (Standard EN 15316-4-5, 2017). Thus, the primary energy factor is calculated by:

$$
f_{p}=\frac{\sum E_{i} f_{p, i}+Q_{e x t} f_{p, e x t}+E_{e l, a u x} f_{p, e l}}{\sum Q_{d e l, j}}
$$

Where:

$E_{i}[J M W h] \quad-$ Energy content of input to the system of the $i^{\text {th }}$ energy carrier,

$f_{p, i}[/] \quad-$ Primary energy factor of the $i^{\text {th }}$ energy carrier,

$\mathrm{Q}_{\text {ext }}[\mathrm{MWh}] \quad$-Externally supplied heat,

$\mathrm{f}_{\mathrm{p}, \mathrm{ext}}[/] \quad$ - Primary energy factor of the external heat supply,

$\mathrm{E}_{\mathrm{el}, \mathrm{aux}}[\mathrm{MWh}]$ - Auxiliary electricity,

$\mathrm{f}_{\mathrm{p}, \mathrm{el}}[/]$ - Primary energy factor for electricity production,

$\mathrm{Q}_{\mathrm{del}, \mathrm{j}}[\mathrm{MWh}]$ - Delivered heat to the $\mathrm{j}^{\text {th }}$ consumer. 


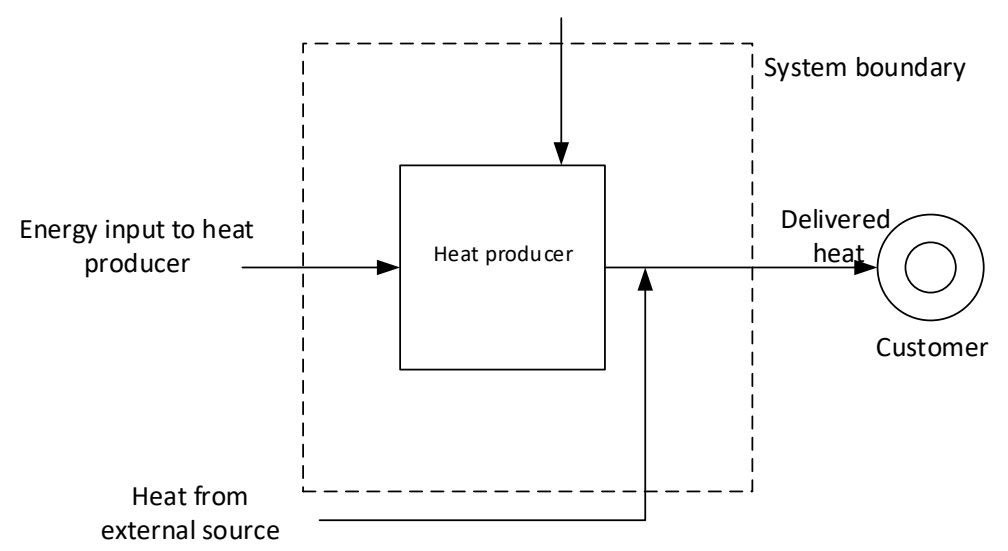

Figure 2. System boundaries for determining energy efficiency rating of DH system (Ecoheat4cities, 2016)

Useful annual heat supplied per Degree Day and heating area (qDD) introduces the effect of climate conditions on consumers heat demand. This indicator makes customers' demands comparable regardless of climate conditions, focusing on the efficiency of the buildings and consumers behaviour. It is calculated by:

$$
\mathrm{q}_{\mathrm{DD}}=\frac{\sum \mathrm{Q}_{\mathrm{del}, \mathrm{j}}}{\mathrm{DD} \cdot \sum \mathrm{A}_{\mathrm{i}}}\left[\frac{\mathrm{MWh}}{\mathrm{m}^{2} \mathrm{DD}}\right]
$$

\section{Where:}

$Q_{\text {del, }}[\mathrm{MWh}]$ - Delivered heat to the $\mathrm{j}^{\text {th }}$ consumer,

$\mathrm{DD}[/] \quad$ - Number of degree days,

$\mathrm{A}_{\mathrm{i}}\left[\mathrm{m}^{2}\right] \quad-$ Heating area of the $\mathrm{i}^{\text {th }}$ consumer.

In the approach adopted in this research, the value of useful annual heat supply per degree day and per heating area remains as the current value, providing a straightforward evaluation of the effects of utilization of wastewater heat.

\section{Energy supply}

Import dependency $\left(\mathbf{I}_{\mathbf{d}}\right)$ describes the dependency on imported energy sources. Usually, this is determined at the level of the state based on the energy balance, but in this research, it is calculated at a level of DH systems. It is determined as a ratio between net imports and primary energy supply:

$$
I_{d}=\frac{\text { Net Imports }}{\text { Primary Energy Supply }}
$$

Where Net imports represents a difference between imports and exports of energy carrier:

$$
\text { Net Imports = Imports }- \text { Exports }
$$

Alternatively, import dependency can be calculated as the sum of import dependencies of each energy carrier (fuel), as follows:

$$
I_{d}=\sum p_{i} I_{d, i}
$$

$I_{d, i}[/] \quad$ - Import dependency of the $\mathrm{i}^{\text {th }}$ energy carrier/fuel utilized in DH systems, calculated by eq. (4)

$\mathrm{p}_{\mathrm{i}}[/] \quad$ - Fraction of the $\mathrm{i}^{\text {th }}$ input energy carrier/fuel in the fuel mix $\left(\sum p_{i}=1\right)$

Fuel mix diversification $\mathbf{( H )}$ is most commonly assessed by the Shannon Wiener diversity index. Diversity of fuel source mix describes one dimension of security-robustness against interruptions of any source (Liang-huey Lo, 2011). The higher the value of the Shannon Wiener index, the more diverse the system is. The Shannon Wiener index is calculated by: 
where

$$
\mathrm{H}=-\sum \mathrm{p}_{\mathrm{i}} \ln \left(\mathrm{p}_{\mathrm{i}}\right)
$$

$p_{i}[/] \quad$ - Fraction of input energy carrier/fuel $i$ in the fuel mix $\left(\sum p_{i}=1\right)$

Where:

$$
\dot{\mathrm{Q}}_{\mathrm{w}}=\dot{\mathrm{m}} \cdot \mathrm{c} \cdot \Delta \mathrm{t}
$$

$\dot{\mathrm{Q}}_{\mathrm{W}}[\mathrm{kW}] \quad-$ Recoverable heat power treated sewage wastewater, $\dot{\mathrm{m}}\left[\frac{\mathrm{kg}}{\mathrm{s}}\right] \quad$ - Mass flow of treated wastewater, $\mathrm{c}\left[\frac{\mathrm{kJ}}{\mathrm{kgK}}\right] \quad$-Specific thermal capacity of treated wastewater, $\Delta \mathrm{t}[K] \quad-$ Temperature difference of treated wastewater at entrance and exit of heat exchanger-evaporator.

The temperature difference is the major variable in calculating the theoretical heat potential of wastewater treatment plants. In general, the common range of $\Delta \mathrm{t}$ is 3-5K (Somogy et al., 2016). For this research, a temperature difference of $4 \mathrm{~K}$ is applied.

Heat energy is produced in heat pumps by utilizing recoverable heat: 
(David et al. 2017) showed that value of COP of large heat pumps operating in district heating systems in Europe in the most cases was between 3 and 4, but closer to 3. (Jasper et al., 2021) presented correlation between COP and temperature deference $\left(\Delta \mathrm{t}_{\text {lift }}\right)$ between treated wastewater and supply water in DH. Higher temperature difference corresponds to lower values of COP.The heating regime in Serbian district heating systems is 90/70C, so temperature at the exit of the heat pump should higher than $70^{\circ} \mathrm{C}$. The experience of implementation of largescale heat pumps in Europe shows that in such cases, values of COP are between 2.5 and 3.5 (European Heat Pump Association, 2017). For this research a conservative approach is adopted, and value of COP 3 is applied.

Indicator that determines availability of heat energy represents heat energy produced by heat pumps per citizen per heating season:

$$
\mathrm{q}_{\mathrm{HP}}=\frac{\mathrm{Q}_{\mathrm{HP}}}{\mathrm{n}}
$$

$\mathrm{Q}_{\mathrm{HP}}[\mathrm{kWh}] \quad$ - Heat energy produced by heat pumps in a heating season,

$\mathrm{n}[/] \quad$-Number of inhabitants in selected city

Indicator of primary energy savings in DH systems (calculated per capita) is determined according to data of produced heat delivered per heating season per citizen, as

$$
\mathbf{q}_{\mathbf{P E}}=\frac{\mathbf{q}_{\mathrm{HP}}}{\eta} \quad\left[\frac{\mathbf{k W h}}{\text { citizen }}\right]
$$

where $\eta$ represents the efficiency of heat production in the existing DH system.

For the cities without WWTPs values of indicators are used for obtaining the projection of the future state of district heating systems and calculation of selected indicators.

\section{PERFORMANCE OF THE DISTRICT HEATING SYSTEMS IN SERBIA - CURRENT STATE}

Energy consumption in buildings (residential, public, and commercial) accounts for $45.45 \%$ of final energy consumption in Serbia (Statistical Office of the Republic of Serbia, 2017). The highest share of energy consumed in the buildings sector, more than $60 \%$, is related to space heating (Econoler, 2012), (Stoiljković and Todorović, 2015).

District heating systems exist in 57 towns in Serbia (Figure 3). The total installed capacity of district heating plants is over 6,500 MW. In 2017, the total heated area was 42.34 million $\mathrm{m}^{2}$, with a share of households of $81 \%$ (Association of Serbian district heating companies, 2018). Approximately $20 \%$ of the total number of households in Serbia and $43.8 \%$ of households in cities is supplied with heat from district heating systems (Association of Serbian district heating companies, 2018), (Statistical Office of the Republic of Serbia, 2013). In some urban areas (Bor, Novi Beograd) this share is over 90\% (Association of Serbian district heating companies, 2018).

Currently, heat production in district heating systems in Serbia is completely based on combustion processes. Fossil fuels are dominantly used $(99.5 \%)$, while the rest is related to wood biomass (Statistical Office of the Republic of Serbia, 2017). Locally available energy sources: municipal solid waste, waste heat from sewage wastewater, industrial waste heat that can be used only in centralized supply systems, are not utilized.

The average efficiency of heat production (boilers) is $83.5 \%$, while heat losses in the district heating networks are approximately 15\% (Association of Serbian district heating companies, 2018) (PU Beogradske elektrane, 2018). Energy consumption in district heating systems in Serbia in 2017. was 26,322.8 TJ with the structure presented in figure 4. The auxiliary electricity consumption was 9,321 TJ (Statistical Office of the Republic of Serbia, 2017).

The fuel with the highest share, natural gas, is dominantly an imported energy source. Import is performed through a single import route from Russia via Ukraine (Madžarević et al., 2018). The second most used fuel, heavy oil, is produced in the country, but mainly from imported oil. Only coal and wood fuel can be considered as indigenous energy sources. Gas import dependency of $82.1 \%$ and oil import dependency of $75.9 \%$, makes overall import 
dependency of district heating systems in Serbia of $71.7 \%$. High import dependency and unfavorable diversification of energy sources indicate the high vulnerability of the customers connected to district heating systems. Average values of key performance indicators of the current state of the district heating systems are given in Table 1.

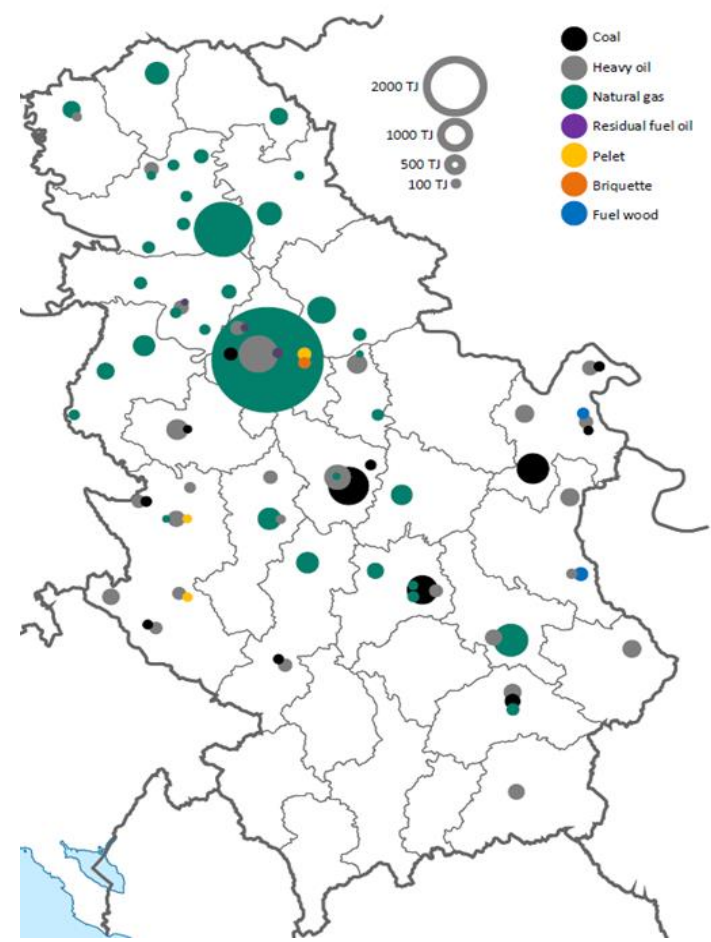

Figure 3. Overview of district heating systems in Serbia, by fuel and by size

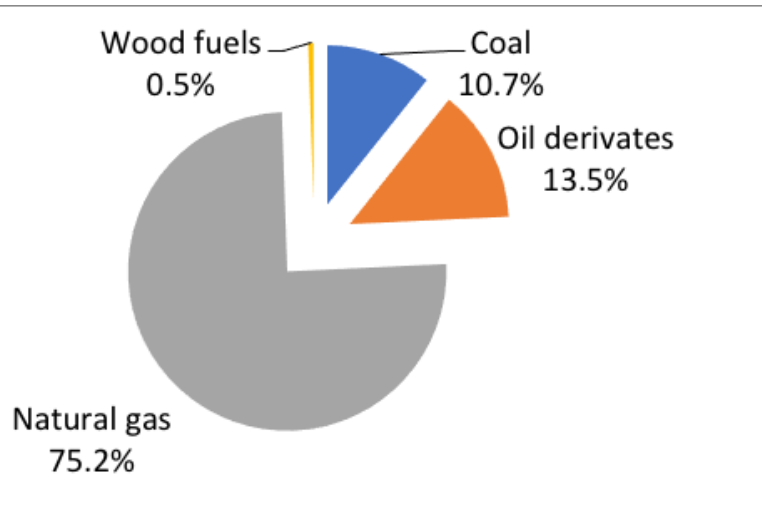

Figure 4. Structure of fuel consumption in district heating systems in Serbia in 2017

Table 1. Average values of the key performance indicators of the district heating systems in Serbia

\begin{tabular}{|l|l|l|}
\hline \multirow{4}{*}{ Energy source } & Indicator & Value in 2017 \\
\cline { 2 - 3 } & Share of renewable energy sources & $0.5 \%$ \\
\cline { 2 - 3 } & Import dependency of district heating systems & $71.7 \%$ \\
\cline { 2 - 3 } \begin{tabular}{l}
\multirow{2}{*}{$\begin{array}{l}\text { Energy } \\
\text { performance }\end{array}$} \\
Emission
\end{tabular} & Primary energy factor & 0.788 \\
\cline { 2 - 3 } & Specific useful annual heat per Degree Day and per heating area & 1.52 \\
\hline
\end{tabular}

High values of the primary energy factor (1.52) and the carbon dioxide emission coefficient (328.3 kg/MWh) are consequences of fossil fuels-based heat production. 
Due to the different structure of input fuels, the efficiency of the systems, and the efficiency of the buildings, values of the indicators vary for the different DH systems. Table 2 presents values for the biggest systems in Serbia.

Table 2. Key performance indicators for the biggest DH systems in Serbia

\begin{tabular}{|l|l|l|l|l|c|}
\hline City/Municipality & $\begin{array}{l}\% \text { of households } \\
\text { connected to DH }\end{array}$ & $\begin{array}{l}\text { Primary } \\
\text { factor }\end{array}$ & $\begin{array}{l}\text { Import } \\
\text { dependency }\end{array}$ & $\begin{array}{l}\text { Shannon } \\
\text { Wiener index }\end{array}$ & $\begin{array}{l}\mathrm{CO}_{2} \text { emission } \\
\text { coefficient } \\
\text { (kg/MWh) }\end{array}$ \\
\hline Belgrade & 49.03 & 1.51 & 80.99 & 0.31 & 316.77 \\
\hline Novi Sad & 75.00 & 1.47 & 82.10 & 0.00 & 301.67 \\
\hline Kragujevac & 33.00 & 1.72 & 18.44 & 0.56 & 532.38 \\
\hline Niš & 29.00 & 1.53 & 81.48 & 0.14 & 322.01 \\
\hline Pančevo & 37.00 & 1.54 & 82.10 & 0.00 & 317.50 \\
\hline Bor & 91.40 & 1.72 & 0 & 0.00 & 560.96 \\
\hline Kruševac & 42.80 & 1.58 & 6.11 & 0.00 & 502.83 \\
\hline Zrenjanin & 28.00 & 1.47 & 82.10 & 0.00 & 301.67 \\
\hline Kraljevo & 11.50 & 1.46 & 81.2 & 0.41 & 310.43 \\
\hline Čačak & 35.00 & 1.51 & 82.01 & 0.08 & 312.13 \\
\hline Jagodina & 47.86 & 1.56 & 82.10 & 0.00 & 320.87 \\
\hline Šabac & 39.15 & 1.53 & 82.10 & 0.00 & 314.19 \\
\hline
\end{tabular}

It can be seen that DH systems with the lowest primary energy factor and carbon dioxide emission coefficient have the highest import dependency since they are relying on a single input fuel - natural gas (Novi Sad, Pančevo, Subotica, Jagodina, Šabac). The other group of DH systems is characterized by high values of primary energy factor and carbon dioxide coefficient, as well as by low import dependency (Kragujevac, Kruševac, Bor). These systems are mainly fueled by a domestic energy source: coal. Values of the Shannon Wiener index point out unfavourable diversification of fuel mix for both groups of DH systems. The weaknesses of the first group of DH systems are high import dependency and unfavourable diversification of fuel mix. Although the second group is not dependent on import fuels, it relies on the most carbon-intensive fuel: coal. The share of renewable energy sources in both groups is negligible. Therefore, none of the DH systems in Serbia can be described as sustainable.

\section{ASSESSMENT OF HEAT POTENTIAL OF TREATED SEWAGE WASTEWATER IN SERBIA}

There are only seven wastewater treatment plants in operation in Serbia (Ministry of environmental protection, 2018). In a few cities, constructions of wastewater treatment plants are taking place, while in several cities preparation of projects has been initiated, so construction of wastewater treatment plants can be expected in the near future (Ministry of environmental protection, 2019). One of the newest and most contemporary wastewater plant (in the city of Šabac) was selected in this paper, for the evaluation of sewage wastewater heat potential and determination of heat potential per inhabitant. Obtained results were then applied for other Serbian cities with DH systems. This approach is justified since the construction of wastewater treatment plants is planned in the cities that already have district heating systems.

The wastewater treatment plant in Šabac has been in operation since 2016. The plant consists of a water line with a capacity of 84,000 population equivalents (PE) and some elements of the sludge line for a capacity of 126,000 PE. Digesters for the treatment of sludge and biogas production facilities are under construction. Currently, approx. 60,000 inhabitants are connected to the existing plant

Data on average monthly temperature of treated water and river Sava (recipient) are presented in table 3. Even in the winter period, the temperature of treated water is higher than $11^{\circ} \mathrm{C}$, so it is adopted to be a minimal available temperature of the heat source. For calculations, the flow rate of 286 1/s of discharged water is adopted.

Table 3. Temperature of treated water and river Sava (recipient), $\left({ }^{\circ} \mathrm{C}\right)$

\begin{tabular}{|l|l|l|l|l|l|l|l|l|l|l|l|l|}
\hline Month & Jan. & Feb. & Mar. & Apr. & May & Jun. & Jul. & Aug. & Sep. & Oct. & Nov. & Dec. \\
\hline Treated water & 11.1 & 11.3 & 14.1 & 15.9 & 18.8 & 22.2 & 23.8 & 24.2. & 21.8 & 19.7 & 15.8. & 12.2 \\
\hline
\end{tabular}




\begin{tabular}{|l|l|l|l|l|l|l|l|l|l|l|l|l|}
\hline Sava & 3.1 & 3.9 & 6.9 & 11.2 & 15.8 & 19.8 & 22.5 & 23 & 18.9 & 13.8 & 8.6 & 4.8 \\
\hline
\end{tabular}

Based on assumptions of the temperature difference in the heat exchanger of $4 \mathrm{~K}$ and the value of the coefficient of performance COP 3 and using equations (9) and (10), the recoverable heat power of treated wastewater $\left(\dot{\mathbf{Q}}_{\mathbf{w}}=\right.$ $4.8 \mathrm{MW})$ and the thermal capacity of heat pump $\left(\dot{\mathbf{Q}}_{\mathbf{h}}=\mathbf{7 . 2} \mathbf{M W}\right)$ are determined.

The heat load duration curve of the DH system in Šabac is presented in Figure 5 (Market uptake of small modular renewable district heating and cooling grids for communities, 2018). The base load of the system is 9 MW, and therefore the heat pump would serve as a base load facility. The heat pump could operate 2,800 hours per year (whole heating season) and deliver $\mathrm{Q}_{\mathrm{HP}}=20,160 \mathrm{MWh}$ of heat to the DH network. The rest of the required heat energy would be provided by existing boilers fueled by natural gas. In the city of Šabac there is no centralized domestic hot water supply, which is also the case for almost all other cities with district heating system in Serbia (Association of Serbian district heating companies, 2018). Such conditions affect the determination of technical potential of wastewater heat, since the operation of the heat pump is determined by the number of operating hours of the district heating system.

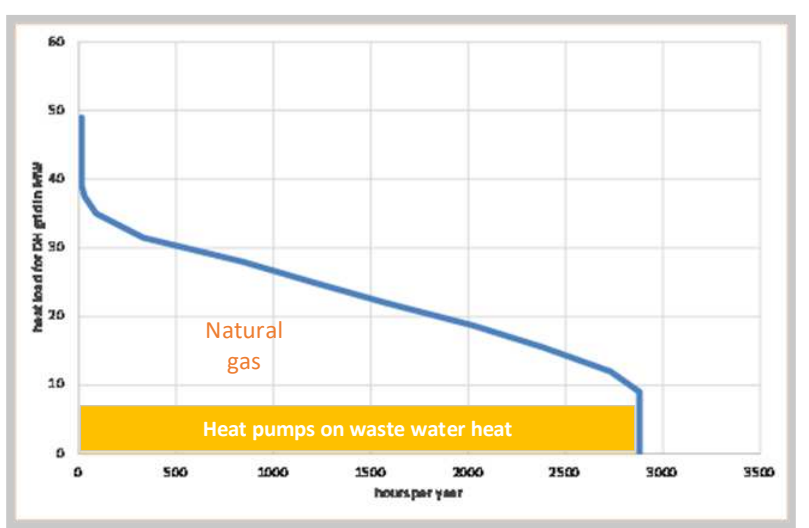

Figure 5. The heat load duration curve of DH system in Šabac and share of energy sources in future system

The ratio between the heat produced in heat pumps $\left(\mathrm{Q}_{\mathrm{HP}}\right)$ and the number of inhabitants connected to the treatment plant gives an indicator of possible heat energy that can be produced in the system with the heat pump in wastewater treatment plant. Based on presented data from the city of Šabac, it was determined using equation (11) that by utilizing wastewater heat, can be produced $\mathrm{q}_{\mathrm{HP}}=379.8 \mathrm{kWh}$ of heat energy per inhabitant per heating season. This value was then used for a rough determination of the theoretical potential of this energy source in Serbia.

\section{POSSIBLE EFFECTS OF INTRODUCTION WASTEWATER HEAT PUMPS IN DISTRICT HEATING SYSTEMS IN SERBIA}

The heat energy that can be produced utilizing wastewater heat in Šabac was the base for estimating amounts of heat that could be produced in the existing DH systems in Serbia if heat pumps were widely implemented. The main input parameter was the calculated indicator of produced heat energy per inhabitant. In order to make results of the key performance indicators comparable, it was assumed that the heating area, the efficiency of buildings, and DH networks would be the same as in the base year. The obtained structure of energy sources in Serbian DH systems, in that case, is presented in Figure 6, while the corresponding values of key performance indicators are presented in Table 4.

Utilization of the potential of treated wastewater by heat pumps, in all Serbian cities with DH systems, would result in the production of 6,360 TJ of heat. As a consequence of the introduction of more efficient technology in heat production, the Primary energy factor will be reduced to 1.467 . This value is also highly influenced by the structure of the Serbian electricity sector, dominantly based on lignite fuelled thermal power plants (Statistical Office of the Republic of Serbia, 2017). Total energy savings including production, transport, and conversion are determined to $1229.8 \mathrm{TJ}$, which is approximately $5 \%$ of the energy currently used. 


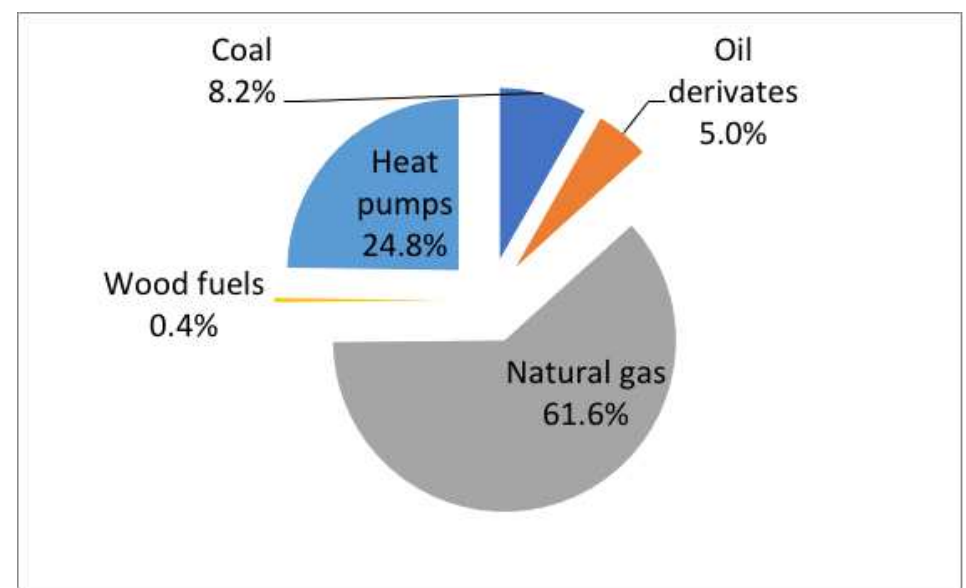

Figure 6. Structure of heat production by source

Table 4. Key performance indicators of the district heating systems in Serbia in the case of wastewater heat pumps implementation

\begin{tabular}{|l|l|l|}
\hline \multirow{3}{*}{ Energy source } & Indicator & Projected value \\
\cline { 2 - 3 } & Share of renewable energy sources & $10.68 \%$ \\
\cline { 2 - 3 } & Import dependency of district heating systems & $64.7 \%$ \\
\cline { 2 - 3 } $\begin{array}{l}\text { Energy } \\
\text { performance }\end{array}$ & Primary energy factor & 0.959 \\
\cline { 2 - 3 } & Specific useful annual heat per Degree Day and heating area & 4.467 \\
\hline Emission & Carbon dioxide emission coefficient & $44.8 \times 10^{-6} \frac{\mathrm{MWh}}{\mathrm{m}^{2} \mathrm{DD}}$ \\
\hline
\end{tabular}

Besides reducing energy consumption, utilization of wastewater heat will induce other positive effects on the supply side by contributing to the increase in energy security. Share of renewable energy sources will increase from $0.5 \%$ to $10.68 \%$. In addition, using this wastewater heat potential reduces import dependency of DH systems to $64.7 \%$ and provides a more diverse energy mix (increased value of the Shannon Wiener index is 0.959 ).

Contribution to GHG emission reduction is also significant. Emission of carbon dioxide decreases from 328.3 to $307 \mathrm{~kg}$ per useful MWh of heat energy, which represents the reduction of carbon dioxide emission from district heating systems of $6.5 \%$. The slightly bigger emission reduction compared to energy reduction is due to the assumption that waste heat as heat source would firstly substitute environmentally less acceptable fuels (coal and heavy fuel oil).

Analyses of expected effects can be further elaborated at the level of cities or DH companies. For the comparison with the present state and exploring effects of heat pumps introduction in district heating systems, expected values of key performance indicators for the biggest DH systems in Serbia are presented in Table 5.

Table 5 Expected values of key performance indicators for the biggest DH systems in Serbia ${ }^{\dagger}$

\begin{tabular}{|l|l|l|l|l|l|}
\hline & $\begin{array}{l}\% \\
\text { City/Municipality } \\
\text { households } \\
\text { connected to } \\
\text { DH }\end{array}$ & Primary factor & $\begin{array}{l}\text { Import } \\
\text { dependency }\end{array}$ & $\begin{array}{l}\text { Shannon } \\
\text { Wiener index }\end{array}$ & $\begin{array}{l}\text { Carbon } \\
\text { emission } \\
\text { coefficient } \\
(\mathrm{kg} / \mathrm{MWh})\end{array}$ \\
\hline Belgrade & $49.03 \%$ & $1.45(-4.0 \%)$ & $66.43(-18 \%)$ & $0.49(+0.18)$ & $288.75(-8.8 \%)$ \\
\hline Novi Sad & $75.00 \%$ & $1.41(-4.1 \%)$ & $67.14(-18 \%)$ & $0.47(+0.47)$ & $281.36(-6.7 \%)$ \\
\hline Kragujevac & $33.00 \%$ & $1.66(-3.5 \%)$ & $18.44(0 \%)$ & $0.66(+0.10)$ & $468.47(-12 \%)$ \\
\hline Niš & $29.00 \%$ & $1.44(-5.9 \%)$ & $57.50(-29 \%)$ & $0.61(+0.47)$ & $279.33(-13.3 \%)$ \\
\hline Pančevo & $37.00 \%$ & $1.46(-5.2 \%)$ & $59.35(-28 \%)$ & $0.59(+0.59)$ & $284.94(-10.3 \%)$ \\
\hline Bor & $91.40 \%$ & $1.69(-1.7 \%)$ & $0(0 \%)$ & $0.08(+0.08)$ & $532.37(-5.1 \%)$ \\
\hline
\end{tabular}

†Values in brackets show the changes relative to correspondent values in Table 2. 


\begin{tabular}{|l|l|l|l|l|l|}
\hline Kruševac & $42.80 \%$ & $1.54(-2.5 \%)$ & $6.11(0 \%)$ & $0.71(+0.71)$ & $461.22(-8.3 \%)$ \\
\hline Zrenjanin & $28.00 \%$ & $1.37(-6.8 \%)$ & $54.04(-34 \%)$ & $0.64(+0.64)$ & $263.59(-12.6 \%)$ \\
\hline Kraljevo & $11.50 \%$ & $1.37(-6.2 \%)$ & $57.37(-29 \%)$ & $0.61(+0.20)$ & $266.52(-14.1 \%)$ \\
\hline Čačak & $35.00 \%$ & $1.39(-7.9 \%)$ & $48.34(-41 \%)$ & $0.68(+0.60)$ & $263.64(-15.5 \%)$ \\
\hline Jagodina & $47.86 \%$ & $1.48(-5.1 \%)$ & $62.14(-24 \%)$ & $0.55(+0.55)$ & $291.94(-9.0 \%)$ \\
\hline Šabac & $39.15 \%$ & $1.42(-7.2 \%)$ & $53.84(-34 \%)$ & $0.64(+0.64)$ & $274.14(-12.7 \%)$ \\
\hline
\end{tabular}

Comparison values of key performance indicators in Table 5 with the current values (Table 2) indicates that the utilization of wastewater heat in district heating systems will induce positive effects in all of the analyzed aspects of sustainability: reduced consumption of energy for production (from 1.7 to $12.8 \%$ ), reduced emission of carbon dioxide (from 5.1 to $24.8 \%$ ), reduced import dependency (up to 67\%), increased diversity of fuel mix (Shannon Wiener index increases in the range 0.08-0.71), and increased share of renewable energy sources. These positive effects are obtained for all analyzed DH systems.

However, the effects vary, depending on the fuel mix in the base year, specific efficiency of heat production and distribution, but also depending on the share of households connected to DH and the number of inhabitants. Therefore, for obtaining optimal positive effects of heat pump introduction and before investment decision, every DH system requires more detailed analysis on production (heat sources, network, substations) and consumption side (inner installation, buildings insulation, habits of consumers, etc.).

\section{DISCUSSION AND CONCLUSION}

Energy systems in the future should be sustainable, optimized, and low carbon systems (Rehman Mazhar et al., 2018). With possibilities to accomplish all aforementioned requirements, district heating systems are being transformed into essential components of future energy systems in cities. The pathway towards more sustainable, resource-independent cities should include locally available energy sources whose wider utilization can be provided by centralized supply systems.

This paper presents a methodology for evaluation of the positive effects related to the goals of sustainable development: energy savings, climate change mitigation, and energy security, which can be obtained through utilization of the full technical potential of treated wastewater heat in district heating systems. The methodology should be used for initial determination of this potential and it is based on calculation of heat energy delivered to DH per citizen, and primary energy savings per citizen per heating season. This enables scaling to other district heating systems with similar climate conditions and consumption pattern. As a result, a possible state of DH systems is obtained to evaluate effects of utilization of waste heat by examining values of selected indicators.

The proposed methodology is tested on district heating systems in Serbia, as a case study. The Serbian district heating systems currently belong to second-generation DH systems and need to follow guidelines for these types of energy system in order to transform to more advanced systems. Utilization of renewable energy sources is seen as one of the first steps in this process. The available energy potential of sewage wastewater is presently completely unused in Serbia, and DH systems are optimal options for utilization of that potential. The experiences of developed countries show that the utilization of wastewater heat is a relatively simple way for a significant increase in the share of renewables on the supply side.

Effects of waste heat recovery are demonstrated by quantification of selected indicators. It has been demonstrated that the introduction of wastewater heat pumps would have multiple positive effects:

- $\quad$ Primary energy savings of 5\% per year due to the introduction of more efficient technology with the same efficiency for consumers and level of comfort,

- Reduction of carbon dioxide emission of $6.5 \%$ per year by introducing this alternative renewable energy source and substitution of coal, heavy fuel oil, and natural gas,

- Reduction of import dependency of DH systems for 9.8\%, making them less vulnerable to unpredictable fossil fuel price variation and interruption in supply,

- Improved diversification of energy sources for $21 \%$ by introduction of locally available renewable energy sources.

Although outcomes of this research do not include economical parameters, they can serve as a support in assessing investments in different technical options. The obtained results can be useful for investors, city governments and policy makers by providing them boundary data for decision making. Some of outcomes such as import dependency and fuel mix diversifications should be introduced to policy makers at different levels in order to increase awareness of them 
and to support options that increase energy security of DH systems and the energy system of the country as whole, by making it less vulnerable to geopolitical and other unpredictable circumstances.

Possibility to utilize energy sources that otherwise would be wasted, need to be considered and treated as a big advantage of DH systems. Therefore, the envisaged process of building wastewater treatment plants in Serbia should be followed by detail analyses of possibilities for their integration in the existing DH systems.

\section{ACKNOWLEDGMENTS}

This research was supported by the Ministry of Environmental Protection of the Republic of Serbia, Green fund, contract number 401-00-1207/2018-05.

\section{DECLARATIONS}

\section{Funding}

This research was supported by the Ministry of Environmental Protection of the Republic of Serbia, Green fund, contract number 401-00-1207/2018-05.

\section{Conflicts of interest/Competing interests (include appropriate disclosures)}

541 The authors declare that they have no known competing financial interests or personal relationships that could have 542 appeared to influence the work reported in this paper.

543 Availability of data and material (data transparency)

544 N/A

Code availability (software application or custom code)

N/A

Authors' contributions (optional: please review the submission guidelines from the journal whether statements are mandatory)

Marija Živković: Conceptualization, Methodology, Investigation, Writing - original draft, Writing - review \&

\section{REFERENCES}

Association of Serbian district heating companies - Tops (2018) Data overview for 2017. https://www.toplanesrbije.org.rs/sr/publikacije. Accessed 2 August 2019 (In Serbian)

Averfalk, H, Ingvarsson P, Persson U, Gong M, Werner S (2017) Large heat pumps in Swedish district heating systems. Renew SustEnerg Rev 79:1275-1284. https://doi.org/10.1016/j.rser.2017.05.135

David, A, Mathiesen, B.V, Averfalk, H, Werner, S, Lund, H (2017) Heat Roadmap Europe: Large-Scale Electric Heat Pumps in District Heating Systems, Energies 10(4): 578. https://doi.org/10.3390/en10040578

Duić, N (2015) Is thesuccessofcleanenergyguaranteed?. CleanTechnEnvironPolicy 17:2093-2100. https://doi.org/10.1007/s10098-015-0969-y

Đurđevic, D, Balic, D, Frankovic, B (2019) Wastewaterheatutilizationthroughheatpumps: Thecasestudyof City of Rijeka. JournalofCleanerProduction 231: 207-213. https://doi.org/10.1016/j.jclepro.2019.05.235

Ecoheat4cities (2016) Guidelines for technical assessment of district heating systems. www.euroheat.org/wpcontent/uploads/2016/04/Ecoheat4cities_3.1_Labelling_Guidelines.pdf.Accessed 2 August 2019 
European Commission (2016) An EU Strategy on Heating and Cooling, COM 51 Final. https://ec.europa.eu/energy/sites/ener/files/documents/1_EN_ACT_part1_v14.pdf; Accessed 2 August 2019

European Heat Pump Association (2017) Large scale heat pumps in Europe. Industrial \& Commercial Heat Pump Working Group

(ICHP) https://www.ehpa.org/fileadmin/red/03. Media/03.02_Studies_and_reports/Large heat_pumps_in_Europe MD N_II final4_small.pdf. Accessed 3 August 2019

Fiore, S, Genon, G (2014) Heat recovery from municipal wastewater: evaluation and proposals. Environ EngManag J 13(7):1595-1604. https://doi.org/10.30638/eemj.2014.177

Hepbasli A, Biyik E, Ekren O, Gunerhan H, Araz M (2014) A key review of wastewater source heat pump (WWSHP) systems. Energy Conversion and Management 88:700-722. https://doi.org/10.1016/j.enconman.2014.08.065

Intelligent energy Europe (2017) Heating with wastewater heat Best practice Catalogue. https://www.grazerea.at/cms/upload/wastewaterheat/bp_catalogue_070321.pdf. Accessed 2 August 2019

International Energy Agency (2014) Heating without global warming - Market Developments and Policy Considerations for Renewable Heat. https://www.iea.org/publications/freepublications/publication/FeaturedInsight_HeatingWithoutGlobalWarming FINAL.pdf. Accessed 2 August 2019

International Energy Agency (2016) Energy Technology Perspectives 2016, Towards Sustainable Urban Energy Systems, IEA, Paris

Jesper. M, Schlosser, F, Pag, F, Walmsley, T.G, Schmitt, B, Vajen, K (2021) Large-scale heat pumps: Uptake and performance modelling of market-available devices, Renewable and Sustainable Energy Reviews 137: 110646. https://doi.org/10.1016/j.rser.2020.110646

Kollmann, R, Neugebauer, G, Kretschmer, F, Truger, B, Kindermann, H, Stoeglehner, G, Ertl, T, Narodoslawsky, M (2017) Renewableenergy from wastewater - Practicalaspectsofintegrating a wastewatertreatmentplantintolocalenergysupplyconcepts. JournalofCleanerProduction $\quad$ 155(1):119-129. https://doi.org/10.1016/j.jclepro.2016.08.168

Kontu, K, Rinne, S, Junnila, S (2019) Introducing modern heat pumps to existing district heating systems - Global lessons from viable decarbonizing of district heating in Finland. Energy 166:862-870. https://doi.org/10.1016/j.energy.2018.10.077

Lo, L-H (2011) Diversity, security, and adaptability in energy systems: a comparative analysis of four countries in Asia. World Renewable Energy Congress. Sweden 2011, 2401-2408. https://doi.org/10.3384/ecp110572401

Lu, C, Wang, S, Wang, K, Gao, Y, Zhang, R (2020) Uncovering the benefits of integrating industrial symbiosis and urban symbiosis targeting a resource-dependent city: A case study of Yongcheng, China. J. Clean. Prod 255: 120210. https://doi.org/10.1016/j.jclepro.2020.120210

Maddah, S, Deymi-Dashtebayaz, M, Maddah, O (2020) 4E analysis of thermal recovery potential of industrial wastewater in heat pumps: An invisible energy resource from the iranian casting industry sector. Journal of Cleaner Production 265:121824. https://doi.org/10.1016/j.jclepro.2020.121824

Madžarević A, Ivezić D, Živković M, Tanasijević M, Ivić M (2018) Assessment of vulnerability of natural gas supply in Serbia: State and perspective Energ Policy; 121: 415-425.https://doi.org/10.1016/j.enpol.2018.06.037

Market uptake of small modular renewable district heating and cooling grids for communities Project No: 691679 (2018) Heating/cooling demand and technical concept for district heating/cooling in Šabac. https://www.coolheating.eu/images/downloads/concepts/Report-D4.4-technical-concept-Sabac-Letnjikovac.pdf. Accessed 3 August 2019

Mateu-Royo, C, Sawalha, S, Mota-Babiloni, A, Navarro-Esbrí, J (2020) High temperature heatpumpintegrationintodistrictheatingnetwork. EnergyConversionand Management 210: 112719. https://doi.org/10.1016/j.enconman.2020.112719

Mazhar A.R, Liu S, Shukla A (2018) A state of art review on the district heating systems. Renew SustEnerg Rev 96: 420-439. https://doi.org/10.1016/j.rser.2018.08.005

Meggers, F, Leibundgut, H (2011) The potential of wastewater heat and exergy: Decentralized high-temperature recovery with a heat pump. Energy Build 43 (4):879-86. https://doi.org/10.1016/j.enbuild.2010.12.008 
Meunier, F (2004) Sorption contribution to climate change control. Clean Techn Environ Policy 6:187-195. https://doi.org/10.1007/s10098-003-0226-7

Ministry of environmental protection (2018) Report on environmental issues for 2017. http://www.sepa.gov.rs/download/Izvestaj_2017.pdf. Accessed 3 August 2019

Ministry of environmental protection (2019) CEBs support to projects related to environmental protection. https://www.ekologija.gov.rs/podrska-ceb-a-projektima-zastite-zivotne-sredine-u-srbiji/?lang=lat. Accessed 3 August 2019

Ministry of Mining and Energy (2015) Energy Sector Development Strategy of the Republic of Serbia for the period by 2025 with projections by 2030 . http://www.mre.gov.rs/doc/efikasnostizvori/23.06.02016\%20ENERGY\%20SECTOR\%20DEVELOPMENT\%20STRATEGY\%20OF\%20THE\%20 REPUBLIC\%20OF\%20SERBIA.pdf.Accessed 2 August 2019

Neugebauer, G, Kretschmer, F, Kollmann, R, Narodoslawsky, M, Ertl, T, Stoeglehner, G, Mapping Thermal Energy Resource Potentials from Wastewater Treatment Plants. Sustainability 7:1298813010.https://doi.org/10.3390/su71012988

PU Beogradskeelektrane (2018) Business report for 2017. http://www.beoelektrane.rs/wpcontent/uploads/2018/07/7.1-Izve\%c5\%altaj-o-poslovanju-za-2017.godinu-Prvi-deo.pdf. Accessed 2 August 2019 (In Serbian)

Santin, M, Chinese, D, De Angelis, A, Biberacher, M (2020) Feasibility limits of using low-grade industrial waste heat in symbiotic district heating and cooling networks. Clean Technol Environ Policy 22:1339-1357. https://doi.org/10.1007/s10098-020-01875-2

Sarpong, G, GnaneswarGude, V, Magbanua, B, Truax, D.D (2020) Evaluation of energy recovery potential in wastewater treatment based on codigestion and combined heat and power schemes. Energy Conversion and Management 222:113147. https://doi.org/10.1016/j.enconman.2020.113147

Sayegh, M.A, Jadwiszczak, P, Axcell, B.P, Niemierka, E, Brys, K, Jouhara, H (2018) Heat pump placement, connection and operational modes in European district heating. Energy \& Buildings 166:122-144. https://doi.org/10.1016/j.enbuild.2018.02.006

Somogyi, V, Sebestyén, V, Domokos, E (2018) Assessment of wastewater heat potential for district heating in Hungary. Energy 163:712-721. https://doi.org/10.1016/j.energy.2018.07.157

Spriet, J, McNabola, A, Neugebauer, G, Stoeglehner, G, Ertl, T, Kretschmer, F (2020) Spatial and temporal considerations in the performance of wastewater heat recovery systems. Journal of Cleaner Production 247:119583. https://doi.org/10.1016/j.jclepro.2019.119583.

Standard EN 15316-4-5 (2017) Energy performance of buildings - Method for calculation of system energy requirements and system efficiencies - Part 4-5. District heating and cooling.

Statistical Office of the Republic of Serbia (2013) Installations and auxiliary premises in dwellings. http://publikacije.stat.gov.rs/G2013/Pdf/G20134008.pdf. Accessed 2 August 2019

Statistical Office of the Republic of Serbia (2017) Total energy balance in 2017. http://publikacije.stat.gov.rs/G2018/Pdf/G20185632.pdf. Accessed 2 August 2019 http://www.ingkomora.org.rs/strucniispiti/?stranica=materijalEE; 2015. Accessed 2 August 2019 (In Serbian) 


\section{Figures}

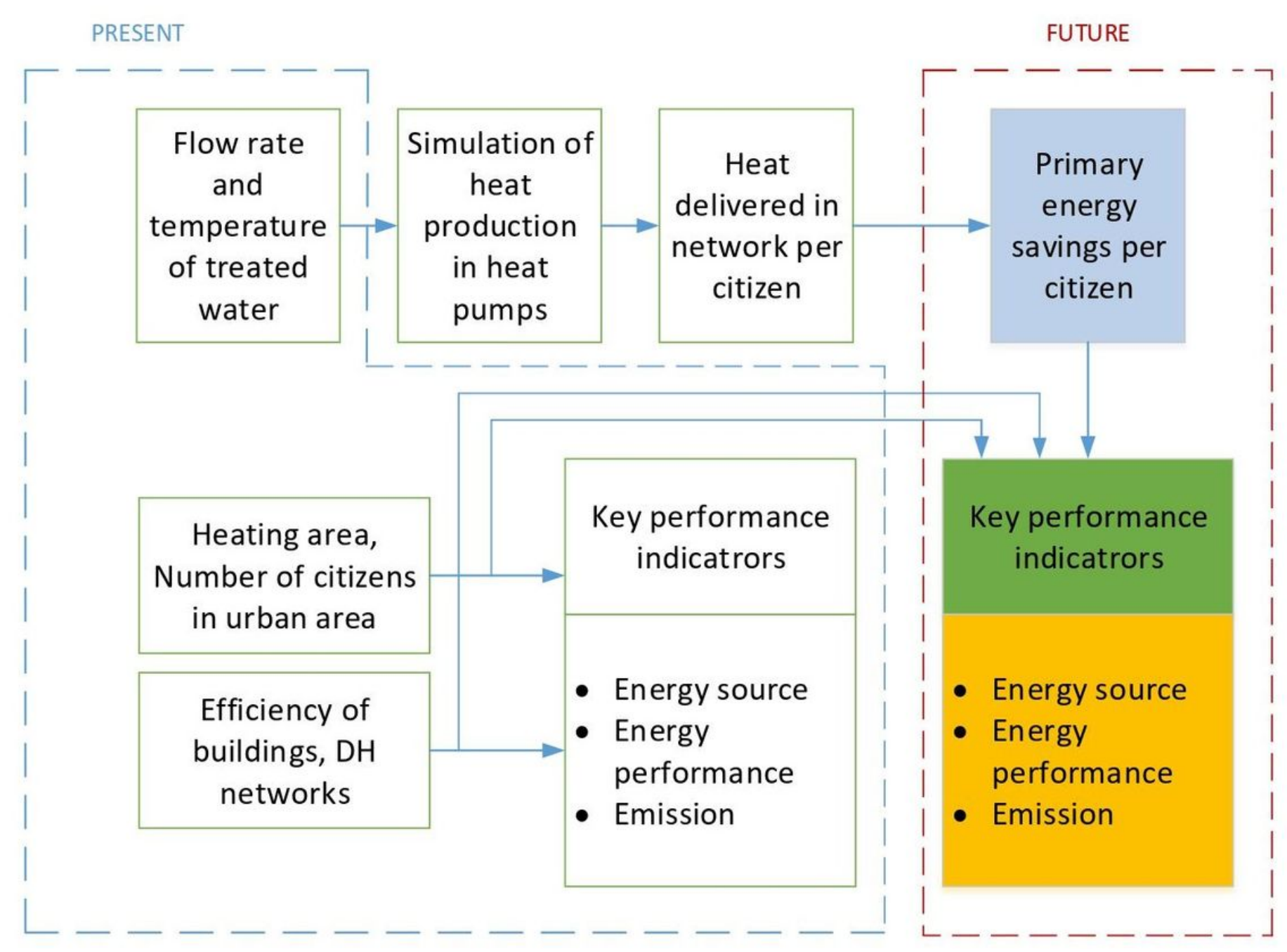

Figure 1

Methodology for evaluation of effects of full recoverable wastewater heat energy potential utilization in district heating systems with heat pumps 


\section{Auxiliary electricity}

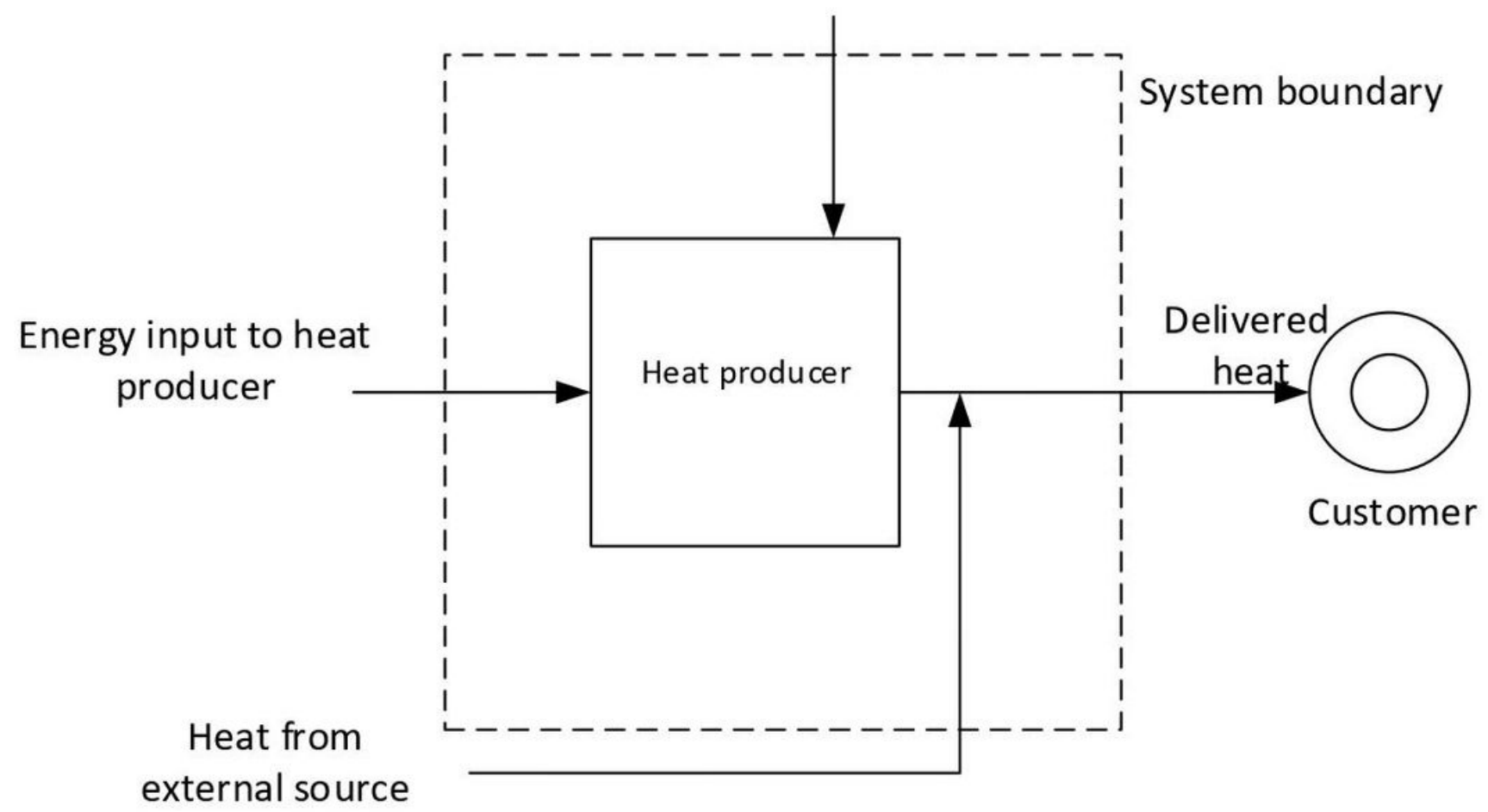

Figure 2

System boundaries for determining energy efficiency rating of DH system (Ecoheat4cities, 2016) 


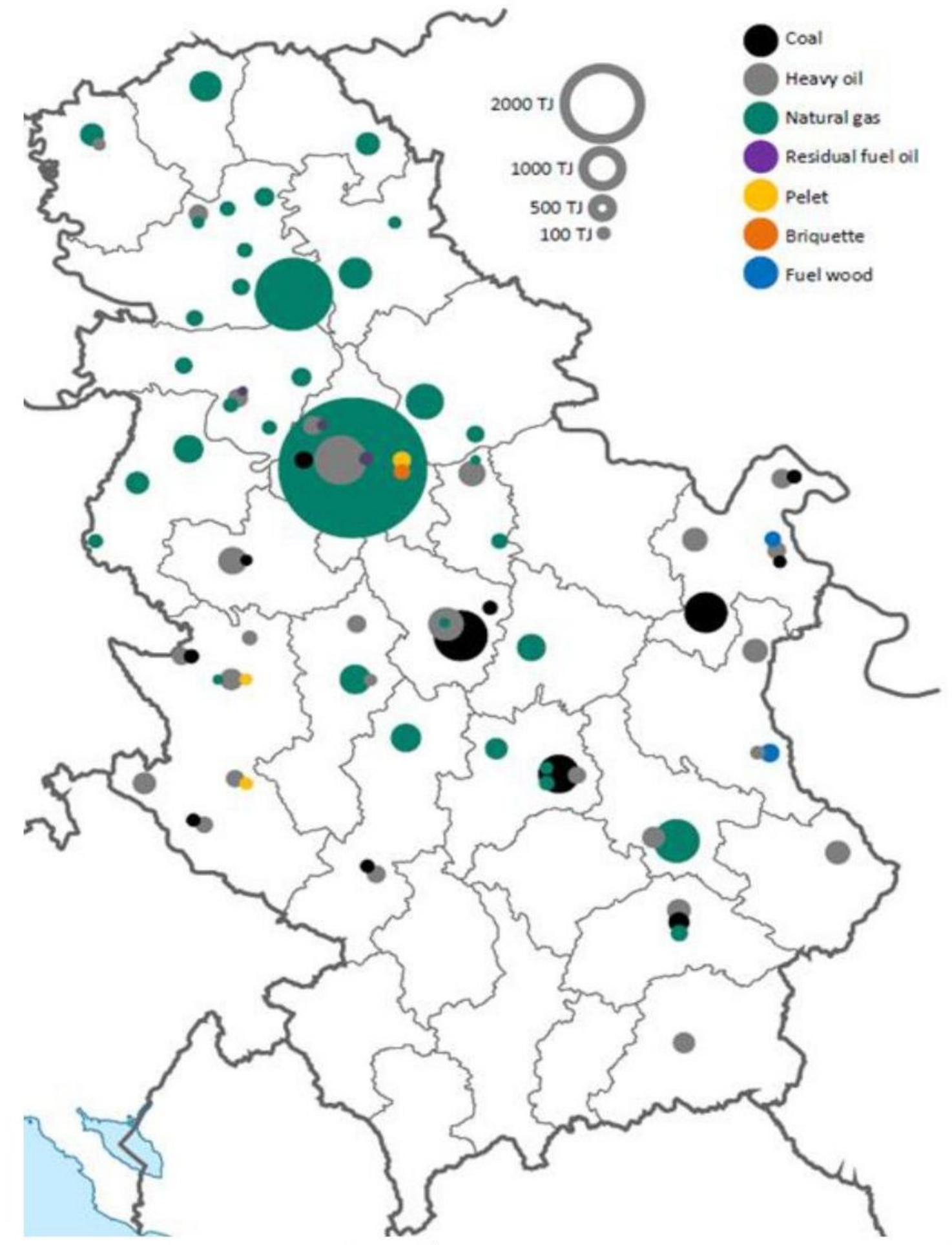

Figure 3

Overview of district heating systems in Serbia, by fuel and by size Note: The designations employed and the presentation of the material on this map do not imply the expression of any opinion whatsoever on the part of Research Square concerning the legal status of any country, territory, city or area or of its authorities, or concerning the delimitation of its frontiers or boundaries. This map has been provided by the authors. 


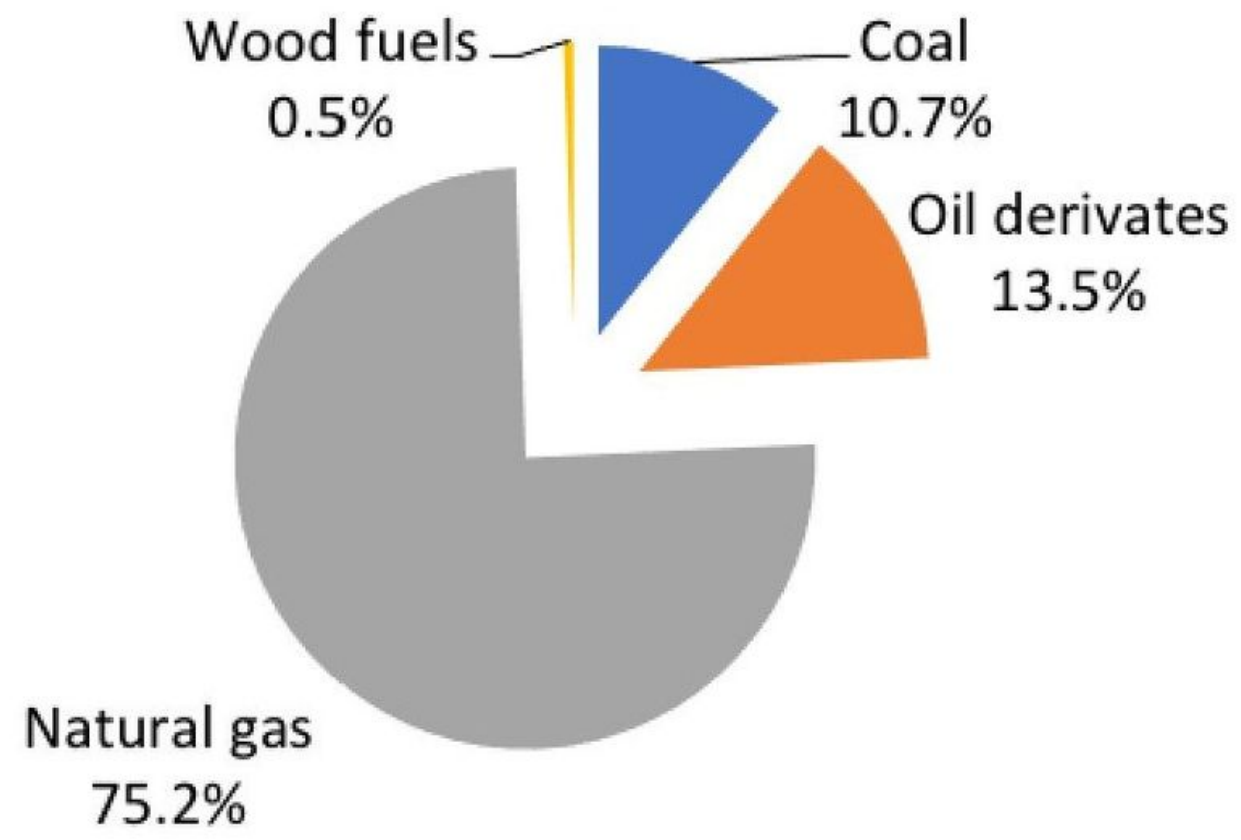

Figure 4

Structure of fuel consumption in district heating systems in Serbia in 2017

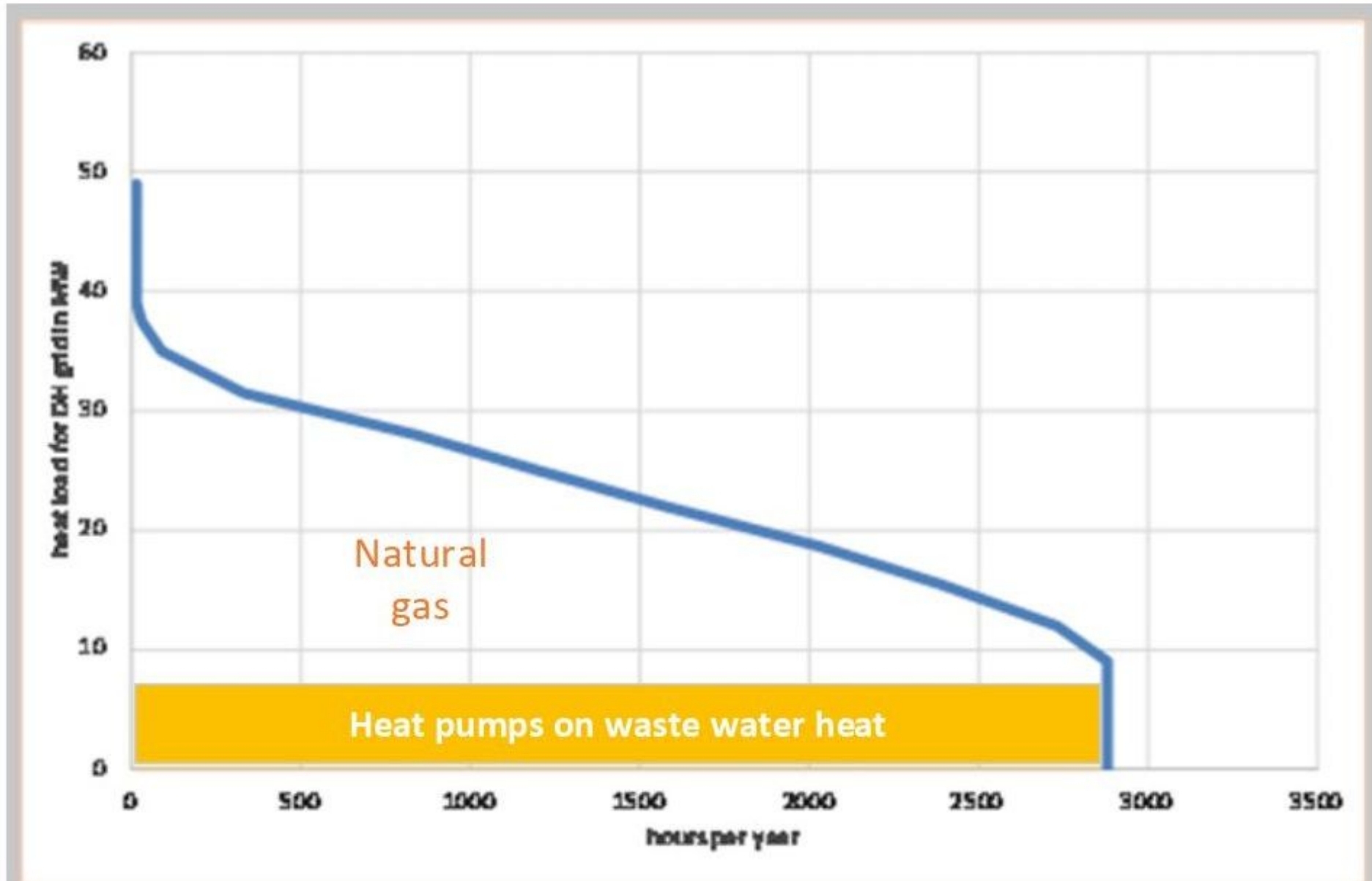


Figure 5

The heat load duration curve of DH system in Šabac and share of energy sources in future system

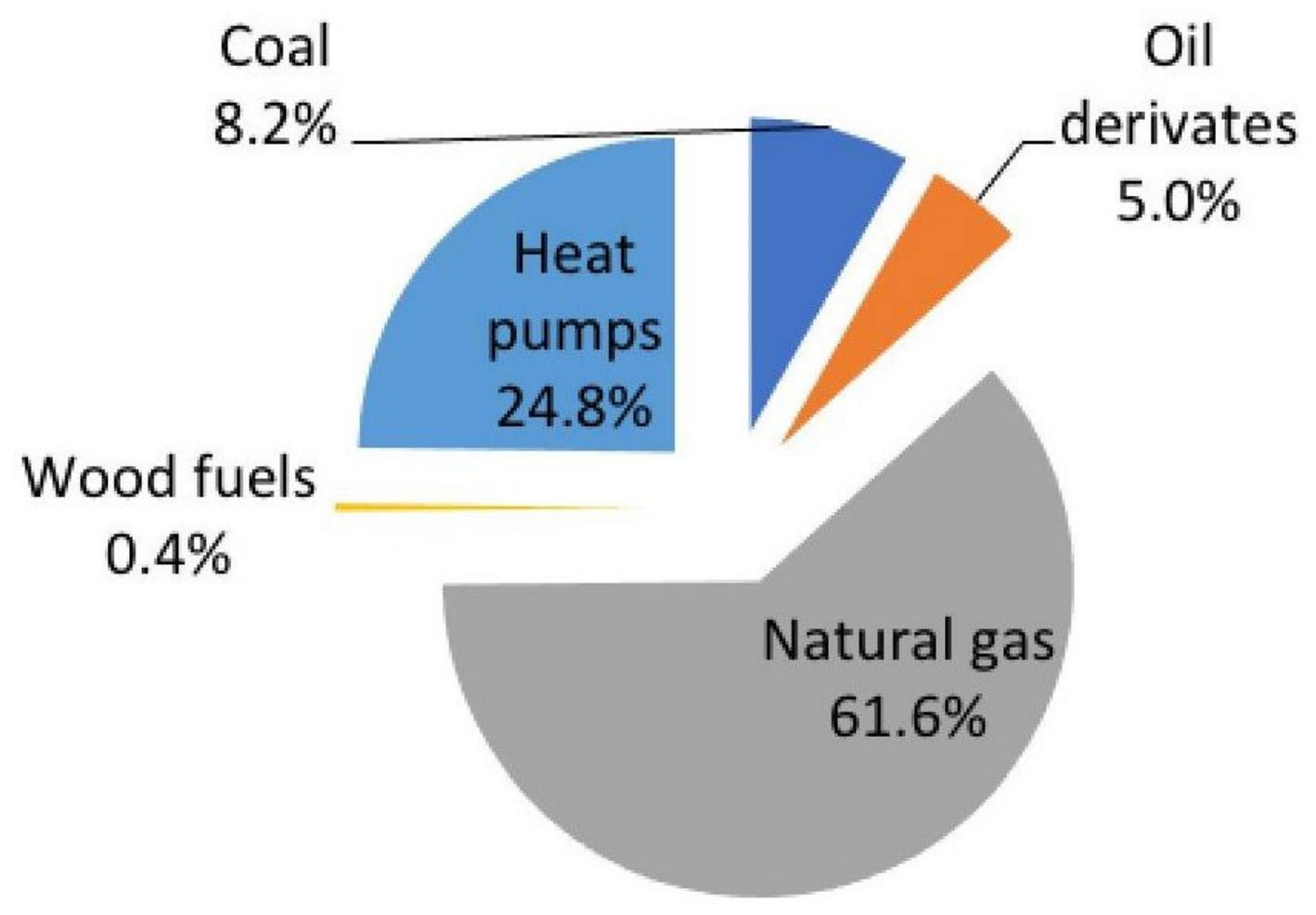

Figure 6

Structure of heat production by source 